\title{
Albizia Lebbeck Stem Bark Aqueous Extract as Alternative to Antibiotic Feed Additives in Broiler Chicks Diets: Haematology Serum Indices and Oxidative Status
}

\author{
Alagbe J. O. (Corresponding Author) \\ Department of Animal Nutrition and Biochemistry Sumitra Research Institute, Gujarat, India \\ Email: demsonfarms@yahoo.com
}

\section{Ajagbe A. D.}

Department of Animal Production Kogi State University, Anyigba, Kogi State, Nigeria

\section{Attama Jeremiah \\ Department of Veterinary Medicine University of Nigeria, Nsukka, Nigeria}

Philemon K. C.

Department of Theriogenology University of Abuja, Nigeria

\section{Bello Kamoru A.}

Al-Hikmah University Ilorin, Nigeria

\author{
Article History \\ Received: 15 August, 2020 \\ Revised: 28 October, 2020 \\ Accepted: 15 November, 2020 \\ Published: 19 November, 2020 \\ Copyright $@ 2020$ ARPG \\ \& Author \\ This work is licensed under the \\ Creative Commons Attribution \\ International \\ (c) (1) \\ c) CC BY: Creative \\ Commons Attribution License \\ 4.0
}

\begin{abstract}
A total of Three hundred and seventy five (375) one day old (Ross 308) broiler chicks with mixed sex were used to examine the effects of Albizia lebbeck stem bark (ATSM) aqueous extract as alternative to antibiotic feed additives in broiler chicks diets: haematology, serum biochemical indices and oxidative status. Birds were divided to five treatments with five replicates of fifteen (15) birds in a completely randomized design. Treatment 1 (basal diet + $0 \%$ ATSM), treatment 2 (basal diet +1.2 grams Oxytetracycline per litre of water), treatment 3 (basal diet $+10 \mathrm{ml}$ ATSM per liter of water), treatment 4 (basal diet $+20 \mathrm{ml}$ ATSM per litre of water) and treatment 5 (basal diet $+30 \mathrm{ml}$ ATSM per liter of water) and the trial lasted for 56 days. Results on some haematological parameters revealed that red blood cell (RBC), pack cell volume (PCV), haemoglobin (Hb), mean corpuscular volume (MCV), mean corpuscular haemoglobin $(\mathrm{MCH})$, mean corpuscular haemoglobin concentration (MCHC), white blood cell (WBC) and its differentials were significantly $((P<0.05)$ different among the treatments. Total protein, glucose, urea, cholesterol, creatinine, aspartate aminotransaminase (AST) and alanine aminotransferase (ALT) were significantly $((P<0.05)$ affected by ATSM. Activities of superoxide dismutase (SDA), glutathione peroxidase (GPx), catalase (CAT) and malonyldialdehyde (MLA) were significantly influenced by ATSM $(P<0.05)$. It was concluded that ATSM could be administered to broiler chicks at $30 \mathrm{ml} /$ litre without any negative effect on the general performance of birds.
\end{abstract}

Keywords: Albizia lebbeck; Broiler chicks; Haematology; Serum biochemical indices.

\section{Introduction}

Phytogenics are heterogeneous group of feed additives emanating from plants and consists of herbs, fruit, spices and other plant parts [1]. According to Veershari, et al. [2], there are over 100, 000 species of plants used globally for medicinal purposes, many have been used in the form of therapy for livestock among resource poor smallholder farmers to treat variety of conditions of animals [3, 4]. Most medicinal plants have been found to be abundant in minerals, vitamins, amino acid and bioactive chemicals [phytochemicals] [5]. However, only a small percentage have been explored or studied for their pharmacological properties [6]. Nutrients in plants have great influence on responses of animals to a disease challenge and it has a direct correlation to the immune system [7]. One of the numerous plant used for therapeutic purposes is Albizia lebbeck.

Albizia lebbeck (Mimosaceae) is a perennial tree native to tropical and subtropical regions of Asia and Africa. The genus Albizia comprises of almost 150 species spread all over India, China, Nigeria, Senegal, Ghana, Togo, Congo, Benin, Angola, Uganda, Botswana among others [8, 9]. The plant parts (stem, leaf and seeds) have been found to be loaded with minerals (calcium, phosphorus, iron, copper, zinc, selenium, molybdenum and potassium), vitamins and amino acids [10-12]. The leaf and stem has traditionally been used for the treatment of fever, tooth ache, wounds, leprosy, ulcer, cold, leprosy, sexually transmitted diseases and other respiratory infections [13, 14].

Several reports on the biological activity of Albizia lebbeck revealed that the plant performs antimicrobial [13], anti-inflammatory [15], antioxidant [16], analgesic [17], antihelminthic [8], hepato-protective [18, 19] antidiabetic [20], immuno-modulatory [17] and antihyperlipidemic properties [21] due to the presence of several bioactive chemicals such as alkaloids, flavonoids, saponins, phenols, tannin etc [13]. In view of these abundant potential, administration of Albizia lebbeck stem bark to birds will possibly supply nutrients to meet all the body's need during a time of challenge. 
Therefore, this experiment was designed to determine the effects of Albizia lebbeck stem bark aqueous extract as alternative to antibiotic feed additives in broiler chicks diets: haematology, serum biochemical indices and oxidative status.

\section{Materials and Methods}

\subsection{Study Area}

The experiment was carried out at Division of Animal Nutrition, Sumitra Research Institute, Gujarat, India during the month of April to June, 2019.

\subsection{Sources Collection and Preparation of Albizia lebbeck Stem Bark Extract}

The stem of Albizia lebbeck stems were obtained from different plants in Gujarat, India and authenticated by a botanist Sharma Xing. The stem bark were cut into pieces and thoroughly washed with distilled water, air dried under the shade to maintain the bioactive chemicals in the test material. The dried samples were pulverized into powder using pestle and mortar, thereafter 250 grams of the sample was soaked into 1000 litres of water, sample was continuously stirred and kept in the refrigerator at $4^{\circ} \mathrm{C}$ for 72 hours. All mixtures were filtered using Whatman filter paper and the filterates (ATSM) were collected into a clean labelled container.

\subsection{Experimental Animals and Management}

Three hundred and seventy five one day old (Ross 308) broiler chicks with mixed sex were used for the experiment. The birds were purchased from a commercial hatchery in India and weighed on arrival on the farm to obtain their initial body weight and thereafter weekly. A deep litter housing system was used, it was fumigated two weeks prior to the commencement of the study, and the surrounding environment was also cleaned daily to ensure proper hygiene. Birds were divided to five treatments with five replicates of fifteen (15) birds in a completely randomized design. Electric brooders were used and wood shavings serve as the litter material. Daily feed intake (g) was calculated as a difference between feed offered and left-over.Vaccines were administered according to the prevailing disease condition in the environment and all other management practices were strictly adhered to throughout the experiment which lasted for 56 days.

\subsection{Ration Formulation}

Three (3) basal diets were formulated at different stages of production to meet up with the requirements of birds according to National Research Council [22]. Broiler starter's mash (0-21 days), growers mash (22-35 days) and finishers mash (36-56 days).

Treatment 1 (basal diet + $0 \%$ ATSM), treatment 2 (basal diet +1.2 grams Oxytetracycline per litre of water), treatment 3 (basal diet $+10 \mathrm{ml}$ ATSM per liter of water), treatment 4 (basal diet $+20 \mathrm{ml}$ ATSM per litre of water) and treatment 5 (basal diet $+30 \mathrm{ml}$ ATSM per liter of water).

\subsection{Parameters Measured}

Proximate compositions of experiment diet were determined by using official method of analysis by AOAC [23]. Amino acid analysis was carried out using amino acid analyzer with ion exchange chromatographic method (Model NH-09b) India.

\subsection{Haematological and Serum Biochemical Analysis}

Blood samples were collected very early in the morning from the wing vein from three (3) randomly selected birds per replicate into a $5 \mathrm{ml}$ sterile syringe using 23 gauge needles and transferred into an ethylene diamine tetra acetic acid (EDTA) bottle. Haematological parameters: pack cell volume (PCV), red blood cell (RBC), haemoglobin $(\mathrm{Hb})$, mean corpuscular haemoglobin $(\mathrm{MCH})$, mean corpuscular haemoglobin concentration (MCHC), mean corpuscular volume (MCV), white blood cell (WBC) and its differentials were analyzed using an automated machine (Sysmex, Model KU-30 HG, India).

Serum analysis was carried out using bottles free from EDTA, blood were analyzed for total protein, albumin, globulin, glucose, cholesterol, creatinine, alanine transaminase (ALT) and aspartate transaminase (AST) were assayed using diagnostic kit manufactured by Merck India Ltd (Model PS-09R) as described by Olubukola, et al. [24].

\subsection{Antioxidant Status}

Activity of superoxide dismutase (SDA), glutathione peroxidase (GPx), catalase (CAT) and malonyldialdehyde (MLA) were carried out using method outlined by Mahipal, et al. [25].

\subsection{Statistical Analysis}

All data were subjected to one -way analysis of variance (ANOVA) using SPSS (18.0) and significant means were separated using Duncan multiple range tests [26]. Significant was declared if $\mathrm{P} \leq 0.05$. 
Table-1. Chemical composition of experimental diets

\begin{tabular}{l|l|l|l}
\hline Materials & Starter (1-21 days) & Grower (22-35 days) & Finisher (36-56 days) \\
\hline Maize & 50.00 & 56.00 & 60.50 \\
\hline Wheat offal & 8.00 & 7.00 & 8.05 \\
\hline Soya meal & 28.55 & 22.00 & 21.00 \\
\hline Groundnut cake & 10.00 & 11.55 & 6.05 \\
\hline Fish meal & 2.00 & 2.00 & 2.00 \\
\hline Bone meal & 0.35 & 0.40 & 0.40 \\
\hline Limestone & 0.20 & 0.20 & 0.20 \\
\hline Lysine & 0.15 & 0.15 & 0.15 \\
\hline Methionine & 0.20 & 0.20 & 0.20 \\
\hline Premix & 0.25 & 0.25 & 0.25 \\
\hline Salt & 0.30 & 0.30 & 0.30 \\
\hline TOTAL & 100.0 & 100.0 & 100.0 \\
\hline Calculated analysis & & & \\
\hline Crude protein & 23.08 & 20.11 & 19.33 \\
\hline Ether extract & 5.03 & 4.87 & 4.28 \\
\hline Crude fibre & 3.06 & 3.95 & 3.42 \\
\hline Calcium & 0.98 & 1.00 & 1.10 \\
\hline Phosphorus & 0.47 & 0.40 & 0.51 \\
\hline Lysine & 1.17 & 1.29 & 1.60 \\
\hline Meth +Cyst & 0.87 & 0.82 & 0.51 \\
\hline ME (Kcal/kg) & 2936 & 3000.8 & 3100.2 \\
\hline
\end{tabular}

*Premix supplied per kg diet: - vit A, 13,000 I.U; vit E, 5mg; vit D3, 3000I.U, vit K, 3mg; vit B2, 5.5mg; Niacin, 25mg; vit B12, 16mg; choline chloride, 120mg; Mn, 5.2mg; Zn, 25mg; Cu, 2.6g; folic acid, 2mg; Fe, 5g; pantothenic acid, $10 \mathrm{mg}$; biotin, $30.5 \mathrm{~g}$; antioxidant, $56 \mathrm{mg}$.

Table-2. Amino acid compositions of Albizia lebbeck stem bark

\begin{tabular}{l|l|l}
\hline Amino acids & Composition $(\mathbf{\%})$ & *Reference level \\
\hline Lysine & 0.86 & 5.50 \\
\hline Arginine & 1.65 & 1.00 \\
\hline Aspartic acid & 2.00 & - \\
\hline Threonine & 1.12 & 0.65 \\
\hline Histidine & 3.45 & 0.30 \\
\hline Serine & 0.78 & - \\
\hline Glycine & 1.00 & 1.20 \\
\hline Alanine & 3.00 & - \\
\hline Cystine & 4.11 & 0.35 \\
\hline Valine & 0.65 & 0.82 \\
\hline Leucine & 1.00 & 1.20 \\
\hline Phenylalanine & 0.34 & 0.50 \\
\hline Tyrosine & 0.10 & 0.45 \\
\hline Isoleucine & 2.00 & 0.60 \\
\hline Proline & 0.03 & 0.20 \\
\hline Methionine & 0.02 & 0.35 \\
\hline$*[2]$ & &
\end{tabular}

Table-3. Haematological parameters of broiler chicks fed different levels ATSM

\begin{tabular}{l|l|l|l|l|l|l}
\hline Parameters & T1 & T2 & T3 & T4 & T5 & SEM \\
\hline PCV $(\%)$ & $26.50^{\mathrm{c}}$ & $29.31^{\mathrm{b}}$ & $31.02^{\mathrm{b}}$ & $33.56^{\mathrm{a}}$ & $34.00^{\mathrm{a}}$ & 0.37 \\
\hline $\mathrm{Hb}(\mathrm{g} / \mathrm{dl})$ & $9.12^{\mathrm{c}}$ & $10.21^{\mathrm{b}}$ & $11.93^{\mathrm{b}}$ & $12.11^{\mathrm{a}}$ & $12.50^{\mathrm{a}}$ & 0.64 \\
\hline $\mathrm{RBC} \times 10^{6} \mu \mathrm{l}$ & $1.88^{\mathrm{c}}$ & $2.00^{\mathrm{b}}$ & $2.10^{\mathrm{b}}$ & $2.60^{\mathrm{a}}$ & $2.97^{\mathrm{a}}$ & 0.07 \\
\hline $\mathrm{MCV}(\mathrm{fl})$ & $111.2^{\mathrm{b}}$ & $119.8^{\mathrm{a}}$ & $120.5^{\mathrm{a}}$ & $123.6^{\mathrm{a}}$ & $130.4^{\mathrm{a}}$ & 8.10 \\
\hline $\mathrm{MCH}(\mathrm{pg})$ & $34.51^{\mathrm{c}}$ & $50.43^{\mathrm{b}}$ & $56.11^{\mathrm{b}}$ & $57.67^{\mathrm{a}}$ & $59.00^{\mathrm{a}}$ & 2.51 \\
\hline MCHC $(\mathrm{g} / \mathrm{dl})$ & $29.80^{\mathrm{b}}$ & $35.60^{\mathrm{a}}$ & $39.00^{\mathrm{b}}$ & $39.10^{\mathrm{a}}$ & $40.03^{\mathrm{a}}$ & 0.88 \\
\hline $\begin{array}{l}\text { WBC } \times 10^{3} \mu \mathrm{l} \\
\text { Differentials }\left(10^{3} \mu \mathrm{l}\right)\end{array}$ & $20.41^{\mathrm{b}}$ & $20.62^{\mathrm{b}}$ & $22.74^{\mathrm{b}}$ & $22.88^{\mathrm{b}}$ & $30.04^{\mathrm{a}}$ & 0.12 \\
\hline Lymphocytes & $10.45^{\mathrm{c}}$ & $14.08^{\mathrm{b}}$ & $15.44^{\mathrm{b}}$ & $18.71^{\mathrm{b}}$ & $20.04^{\mathrm{a}}$ & 1.96 \\
\hline Monocytes & $0.07^{\mathrm{c}}$ & $1.11^{\mathrm{b}}$ & $1.20^{\mathrm{b}}$ & $1.26^{\mathrm{b}}$ & $1.72^{\mathrm{a}}$ & 0.01 \\
\hline Heterophils & $4.23^{\mathrm{b}}$ & $5.06^{\mathrm{a}}$ & $5.40^{\mathrm{a}}$ & $5.89^{\mathrm{a}}$ & $6.11^{\mathrm{a}}$ & 0.41 \\
\hline Eosinophils & $0.88^{\mathrm{b}}$ & $1.02^{\mathrm{a}}$ & $1.09^{\mathrm{a}}$ & $1.21^{\mathrm{a}}$ & $1.27^{\mathrm{a}}$ & 0.02 \\
\hline
\end{tabular}

Means in the same row with different superscript are significantly different $(P<0.05)$ 
Table-4. Serum analysis of broiler chicks fed different levels of ATSM

\begin{tabular}{l|l|l|l|l|l|l}
\hline Parameters & T1 & T2 & T3 & T4 & T5 & SEM \\
\hline Total protein $(\mathrm{g} / \mathrm{dl})$ & $2.57^{\mathrm{b}}$ & $3.22^{\mathrm{a}}$ & $3.69^{\mathrm{a}}$ & $3.88^{\mathrm{a}}$ & $3.97^{\mathrm{a}}$ & 0.67 \\
\hline Albumin $(\mathrm{g} / \mathrm{dl})$ & $1.34^{\mathrm{b}}$ & $1.55^{\mathrm{b}}$ & $1.91^{\mathrm{b}}$ & $2.00^{\mathrm{a}}$ & $2.03^{\mathrm{a}}$ & 0.02 \\
\hline Globulin $(\mathrm{g} / \mathrm{dl})$ & $1.23^{\mathrm{c}}$ & $1.67^{\mathrm{b}}$ & $1.78^{\mathrm{b}}$ & $1.88^{\mathrm{a}}$ & $1.94^{\mathrm{a}}$ & 0.15 \\
\hline Creatinine $(\mathrm{mg} / \mathrm{dl})$ & $0.15^{\mathrm{c}}$ & $0.45^{\mathrm{b}}$ & $0.81^{\mathrm{a}}$ & $0.87^{\mathrm{a}}$ & $0.91^{\mathrm{a}}$ & 0.01 \\
\hline Glucose $(\mathrm{mg} / \mathrm{dl})$ & $196.1^{\mathrm{c}}$ & $204.3^{\mathrm{a}}$ & $234.1^{\mathrm{a}}$ & $241.5^{\mathrm{a}}$ & $250.6^{\mathrm{a}}$ & 4.33 \\
\hline Cholesterol $(\mathrm{mg} / \mathrm{dl})$ & $101.4^{\mathrm{a}}$ & $98.6^{\mathrm{b}}$ & $90.4^{\mathrm{a}}$ & $89.4^{\mathrm{a}}$ & $87.5^{\mathrm{a}}$ & 2.87 \\
\hline Uric acid $(\mathrm{mg} / \mathrm{dl})$ & $7.33^{\mathrm{a}}$ & $4.89^{\mathrm{b}}$ & $4.22^{\mathrm{b}}$ & $4.00^{\mathrm{b}}$ & $3.88^{\mathrm{b}}$ & 0.05 \\
\hline ALT $(\mathrm{u} / \mathrm{l})$ & $74.1^{\mathrm{a}}$ & $70.5^{\mathrm{a}}$ & $61.6^{\mathrm{b}}$ & $58.1^{\mathrm{b}}$ & $50.7^{\mathrm{b}}$ & 1.45 \\
\hline AST $(\mathrm{u} / \mathrm{l})$ & $300.7 \mathrm{a}$ & $288.5^{\mathrm{b}}$ & $230.4^{\mathrm{b}}$ & $218.0^{\mathrm{b}}$ & $200.9^{\mathrm{b}}$ & 9.45 \\
\hline
\end{tabular}

Means in the same row with different superscripts differ significantly $(P<0.05)$

Table-5. Antioxidant status of broiler chicks fed different levels of ATSM

\begin{tabular}{l|l|l|l|l|l|l}
\hline Parameters & T1 & T2 & T3 & T4 & T5 & SEM \\
\hline MLA (U/mg Hb) & $1.85^{\mathrm{c}}$ & $2.77^{\mathrm{b}}$ & $2.93^{\mathrm{b}}$ & $3.04^{\mathrm{a}}$ & $3.11^{\mathrm{a}}$ & 0.03 \\
\hline SDA (U/mg Hb) & $35.7^{\mathrm{b}}$ & $39.8^{\mathrm{b}}$ & $40.7^{\mathrm{a}}$ & $43.5^{\mathrm{a}}$ & $45.3^{\mathrm{a}}$ & 1.21 \\
\hline GPx (U/mg Hb) & $27.1^{\mathrm{b}}$ & $29.4^{\mathrm{b}}$ & $33.8^{\mathrm{a}}$ & $34.7^{\mathrm{a}}$ & $38.3^{\mathrm{a}}$ & 1.96 \\
\hline CAT (U/mg Hb) & $54.2^{\mathrm{a}}$ & $45.7^{\mathrm{b}}$ & $42.5^{\mathrm{b}}$ & $41.6^{\mathrm{b}}$ & $40.1^{\mathrm{b}}$ & 0.52 \\
\hline
\end{tabular}

Means in the same row with different superscripts differ significantly $(P<0.05)$

\section{Result and Discussion}

The proximate composition of experimental diet (Table 1) revealed that it contains crude protein of $23.08 \%$, $20.11 \%$ and $19.33 \%$; energy of $2936.0 \mathrm{kcal}, 3000.8 \mathrm{kcal}$ and $3100.2 \mathrm{kcal}$ for starter, growers and finisher mash. The ether extract range between $(4.28-5.03 \%)$ and crude fibre range between $(3.06-3.95 \%)$. The proximate components meet the nutritional needs of birds according to National Research Council [22]. The crude fibre and ether extract range also conforms to the report of Teodora, et al. [27] in feeding broilers Hermetia illucens meal. The calcium $(0.98-1.10 \%)$ and phosphorus $(0.47-0.51 \%)$ range in the experimental diet is in line with the reports of Fascina, et al. [28]; Aduku [29]. Proper feeding is one of the key cardinals of management in livestock production, for animals to perform at their optimum, there is need to furnish them with proper balanced diet which contains all the necessary nutrients [30].

The amino acid composition of Albizia lebbeck stem bark is presented in Table 2. Results revealed the presence of threonine $(1.12 \%)$, leucine $(1.00 \%)$, lysine $(0.86 \%)$, valine $(0.65 \%)$, glycine $(1.00 \%)$, phenylalanine $(0.34 \%)$, histidine $(3.45 \%)$, methionine $(0.02 \%)$, alanine $(3.00 \%)$, serine $(0.78 \%)$, proline $(0.03 \%)$, aspartic acid $(2.00 \%)$, arginine $(1.65 \%)$, tyrosine $(0.10 \%)$, isoleucine $(2.00 \%)$, aspartic acid $(2.00 \%)$ and cysteine $(4.11 \%)$. The sample contains high concentration of histidine and tyrosine has the lowest concentration. Amino acids are building blocks of protein which are necessary for gene expression and cell signal transduction regulation [31]. Phenylalanine plays a vital role in insulin secretion and fat oxidation [32]. Lysine ensures effective production of hormones, enzymes and energy [33]. Alanine and glutamic acid enables a healthy skeletal system and energy production for the body [34, 35]. Regulation of blood sugar is been assisted by isoleucine [36, 37]. Adequate arginine ensures healthy immune system and maintains the visceral organs in the body $[38,39]$. Serine and cysteine play a key role as neuromodulator and antioxidant respectively [39-41]. Methionine maintains the integrity of the liver, feather formation and egg size or production in birds $[42,43]$.

Haematological parameters of broiler chicks fed different levels of ATSM are presented in Table 4. PCV values ranged between $(26.50-34.00 \%), \mathrm{Hb}(9.12-12.50 \mathrm{~g} / \mathrm{dl}), \mathrm{RBC} 1.88-2.97\left(10^{6} / \mu \mathrm{l}\right), \mathrm{MCV}(111.2-130.4 \mathrm{fl}), \mathrm{MCH}$ $(34.01-59.00 \mathrm{pg})$ and MCHC (29.80 - $40.03 \mathrm{~g} / \mathrm{dl})$. RBC, PCV, Hb, MCV, MCH and MCHC values were higher $(P<0.05)$ in T3, T4 and T5 than for T2 and T1. WBC $20.41-30.04\left(10^{3} / \mu \mathrm{l}\right)$ were highest in T4 and T5 $(P<0.05)$ compared to other treatments. Monocytes $(0.07-1.72 \%)$, lymphocytes $10.45-20.04\left(10^{3} / \mu 1\right)$, heterophils $1.23-$ $6.11\left(10^{3} / \mu \mathrm{l}\right)$ and eosinophils $0.88-1.27\left(10^{3} / \mu \mathrm{l}\right)$ were lowest $(P<0.05)$ in $\mathrm{T} 1$ relative to other treatments. The haematological parameters measured follow similar pattern as it significantly $((P<0.05)$ increased from T1 to T5. However, all values are within the physiological range for normal birds [44-46]. Islam, et al. [47]; Abdi-Hachesoo, et al. [48] reported a $\mathrm{RBC}$ range $\left(2.9-3.510^{6} / \mu \mathrm{l}\right)$, this variation could simply be as a result of differences in age, sex, breed, environment, hormones and nutrition [49]. Haematological indices are used to in disease diagnosis as well as extent of damage to the blood [50, 51]. PCV and MCH are useful indices for the diagnosis of anaemia Nse Abasi, et al. [50]; Alagbe [18]. A higher RBC level is an indication of adequate oxygen in the blood which gives room for effective nutrient transportation in the body $[52,53]$. WBC plays a major role in the immune system by the production of antibodies, animals with low WBC stands a high risk of infection [52, 54].

The serum biochemical indices of the experimental birds are presented in Table 4. Total protein ranges $(2.57-$ $3.97 \mathrm{~g} / \mathrm{dl})$, globulin $(1.23-1.97 \mathrm{~g} / \mathrm{dl})$, albumin $(1.34-2.03 \mathrm{~g} / \mathrm{dl})$, creatinine $(0.51-0.91 \mathrm{mg} / \mathrm{dl})$ and glucose $(196.1-$ $250.6 \mathrm{mg} / \mathrm{dl})$ were lowest $(P<0.05)$ for T1 compared to the other treatments while cholesterol $(87.5-101.4 \mathrm{mg} / \mathrm{dl})$, uric acid $(50.7-74.1 \mathrm{mg} / \mathrm{dl})$, ALT $(50.7-74.1 \mathrm{u} / \mathrm{l})$ and AST $(200.9-300.7 \mathrm{u} / \mathrm{l})$ was higher $(P<0.05)$ for T1 and T2 than for the rest of the treatments. Total protein value in T4 and T5 were significantly higher $(P<0.05)$ compared to the other treatment, this could be attributed to the presence of some relevant nutrients in ATSM. Alagbe [3] Albumin content in the blood are generally influenced by protein shortages, however, the values reorted fall within the range 
reported by Subhadarsini and Silpa [45]. Ibrahim [46] ; Obajuluwa, et al. [55]; Olafadehan, et al. [56]; Livingston, et al. [57] reported a globulin and uric acid range of $(1.6-1.9 \mathrm{~g} / \mathrm{dl})$ and $(3.7-5.2 \mathrm{mg} / \mathrm{dl})$ respectively. This result is also in agreement with the findings of Obiakaonu, et al. [58] and Simeraks, et al. [59]. Cholesterol, creatinine, uric acid, ALT and AST values follow similar pattern as it significantly $(P<0.05)$ decreased from T1 to T5. However, all the values were within the range reported by Olafadehan, et al. [5]. Lower Creatinine and uric acid level is a sign that the kidney is not damage by feeding ATSM to the birds. According to Alagbe [3], ATSM is loaded with several minerals, vitamins and bioactive chemicals or secondary metabolites (tannin, saponin, flavonoids, alkaloids, phenol etc.) which are within the lethal dose for broiler chicks. Urea levels is also reported to be influenced by dietary protein quality, quantity, bleeding time and are sensitive biomarkers employed in the diagnosis of renal damage [60]. ATSM can also be serves as a hypolipidemic substance because of its ability to lower blood cholesterol, thus preventing heart diseases [3]. ALT and AST are serum enzymes triggered due to the presence of a toxic substance in feed $[5,61]$. The result obtain revealed that ATSM did not contain antinutrients or toxic substance which could hinder the general performance of birds, this result confirms the earlier report of Abdel, et al. [62]; Cho, et al. [63] on the effects phytogenic feed additive in broiler chicks.

The oxidative status as influenced by ATSM is presented in Table 5. Superoxide dismutase [SDA; 35.7 - 45.3 $\mathrm{U} / \mathrm{mg} \mathrm{Hb}$, glutathione peroxidase [GPx; 27.1 - $28.3 \mathrm{U} / \mathrm{mg} \mathrm{Hb}$, catalase [CAT; $40.1-54.2 \mathrm{U} / \mathrm{mg} \mathrm{Hb}$ and malonyldialdehyde [MLA; $1.85-3.11 \mathrm{U} / \mathrm{mg} \mathrm{Hb}$ ] values were lowest $(P<0.05)$ in $\mathrm{T} 1$ than in other treatments. According to Alagbe [18], ATSM contains antioxidants which are capable of scavenging free radicals, thereby giving total protection to animals. The presence of phenol and flavonoids prevent oxidative damage to biomolecules, superoxide anions and lipid peroxy radicals [64, 65]. The same results were reported by Lan, et al. [66] who observed that intake of phytogenic feed additives resulted in the increase in serum antioxidant enzyme activities and a decrease in MDA concentration. Conversely, Lan, et al. [66] reported that the concentration of blood glutathione was not affected by phytogenic feed additives.

\section{Conclusion}

Feed additives (plants extracts) have been reported to perform multiple biological activities including antibacterial, antifungal, antiviral, antihelminthic, antioxidant and immune modulator because they contain phytochemicals such as phenols, flavonoids, alkaloids, tannins, saponins, terpenoids etc. They are relatively cheap, safe and effective without any side effect on continuous use. The use of ATSM at $30 \mathrm{ml} /$ litre of water have shown to be able to give total protection to the body and its metabolism against free radicals due to the presence of antioxidants and have no deleterious effect on the blood profile of broiler chicks.

\section{References}

[1] Santi, D. U. and Kim, I. H., 2017. "Efficacy of phytogenic feed additive on performance production and health status of monogastric animals - A review." Annals of Animal Science, vol. 17, pp. 929-948.

[2] Veershari, A. O., Ozegbe, P. C., Ogunjobi, O., Taiwo, V. O., and Adu, J. O., 2011. "Haematological, plasma biochemistry and whole blood minerals of the captive adult African grasscutter." Tropical Veterinarian, vol. 20, pp. 97-100.

[3] Alagbe, J. O., 2020. "Performance, hematology and serum biochemical parameters of weaner rabbits fed different levels of fermented Lagenaria brevifora whole fruit extract." Advances in Research and Reviews, vol. 1, p. 5 .

[4] Mirazaei-Aghsaghali, I., 2012. "Evaluation of the chemical nutritional, antimicrobial and antioxidant vitamin profiles of Piliostigma thonningiileaves." Research Journal of Medicinal Plants, vol. 4, pp. 537539.

[5] Olafadehan, O. A., Oluwafemi, R. A., and Alagbe, J. O., 2020. "Carcass quality, nutrient retention and caeca microbial population of broiler chicks administered Rolfe (Daniellia oliveri) leaf extract as an antibiotic alternative." Journal of Drug Discovery, vol. 14, pp. 146-154.

[6] WHO, 1991. "Guidelines for elemental concentration." Journal of Am. Med, vol. 23, pp. 299-305.

[7] Gary, D. B. and Richard, D. M., 2002. "Interrelationship between nutrition and immunity. VM 139 Series at the Veterinary Medicine - Large Animal Clinical Sciences Dept, UF/IFAS Extension." Large Animal Clinical Sciences Dept, UF/IFAS Extension, vol. 3, pp. 23-29.

[8] Karuppannan, K., 2013. "Phytopharmacological properties of Albizia species: A review." International Journal of Pharmacy and Pharmacological Sciences, vol. 10, pp. 3-9.

[9] Ukpadi, I. and Offor, S., 2018. "Medicinal plants of the world: Chemical constituents, traditional and modernmedicinal uses." Humma Press Inc. New Jersey, vol. 1, pp. 15-31.

[10] Alagbe, J. O. and Soares, D. M., 2018. "Effects of feeding different levels of Azolla pinnata, Polyalthia longifolia, Tithonia diversifolia, Moringa olifera, Azadiracta indica leaf meal infusion as an organic supplement on the performance and nutrient retention of growing grass cutters." Greener Journal of Agricultural Sciences, vol. 8, pp. 01-11.

[11] Mohammed, F., Singh, P. P., and Irchhaiya, R., 2012. "Review on Albizia lebbecka potent herbal drugs." International Research Journal of Pharmacy, vol. 3, pp. 63-68.

[12] Uzoekwe, H. S. and Mohammed, K. W., 2015. "Immune modulation of innate immunity as alternatives to antibiotics strategies to mitigate the use of drugs in poultry production." Journal of Poultry Science, vol. 91, pp. 1286-1291. 
[13] Labaran, I., Lukman, O., Afolabi, A. A., Jamil, D., and Umar, M., 2016. "Analysis of some phytochemical and minerals found in aqueous stem bark extract of Albizia lebbeck." Dutse Journal of Pure and Applied Sciences, vol. 2, pp. 231-237.

[14] Uwaya, J. O., Okunrobo, L. O., and Igbinaduwa, P. O., 2016. "Albizia zygia: A comparative investigation of phytochemical composition, proximate analysis and anti-seizure properties of methanol extracts and its leaves and stem bark." Journal of Phytochemistry vol. 1, pp. 23-27.

[15] Gupta, M., Mazumder, U., Umar, T., Gomathi, P., and Kumar, R., 2004. "Antioxidant and hepatoprotective effects of Bulhiniaracemosa against paracetamol and carbon tetrachloride induced liver damage in rats." Iran Journal of Pharmacological Therapy, vol. 3, pp. 12-20.

[16] Mc Donald, S. D., Prenzler, M., and Robards, K., 2001. "Phenolic content and antioxidant activity of olive extracts." Journal of Food Chemistry, vol. 73, pp. 73-84.

[17] Sharma, Y., Bilbis, L. S., Lawal, M., Hassan, S. W., Abbas, A. Y. I., and Isezuo, S. A., 2007. "Acute and sub chronic toxicity studies of crude aqueous extract of Albizia chevalier." Asian Journal of Biochemistry, vol. 2, pp. 224-236.

[18] Alagbe, J. O., 2019. "Haematology, serum biochemistry, relative organ weight and bacteria count of broiler chicken given different levels of Luffa aegyptiaca leaf extracts." International Journal of Advanced Biological and Biomedical Research, vol. 7, pp. 382-392.

[19] Edeoga, O., Adamu, S., Salami, S. O., and Obadiah, H. I., 2005. "Haematological and plasma biochemical parameters of the young grasscutter reared in the northern Nigeria." Journal ofCell and Animal Biology, vol. 10, pp. 177-181.

[20] Karetu, H. O., Opara, M. N., Okoro, V. M. O., Ogbuewu, I. P., Etuk, E. B., and Udedbie, A. B. I., 2011. "Haematological and serum biochemical indices of starter broilers fed moringaleaf meal." Online Journal ofAnimal and Feed Research, vol. 11, pp. 150-154.

[21] Ueda, O. B., Ajiboye, T. O., Adebanjo, E. O., Balogun, A., and Mohammed, A. O., 2003. "Proximate composition, phytochemical and mineral contents of young and mature Polyalthia longifolia Sonn. Leaves." Fountain Journal of Natural and Applied Sciences, vol. 3, pp. 10-19.

[22] National Research Council, 1994. Nutrient requirement of poultry. 9th ed. Washington D.C.: National Academy Press.

[23] AOAC, 2000. Association of official analytical Chemists. Official methods of analysis. 19th ed. Washington, D.C, pp. 69-77.

[24] Olubukola, S. O., Anthony, J. A., and Adewale, A., 2015. "Sub-chronic administration of methanolic whole fruit extracts of Lagenaria breviflora (Benth) induces mild toxicity in rats." Journal of Pharmacognosy and Natural Product, vol. 11, pp. 516-521.

[25] Mahipal, C., Ashak, K. P., Shalini, B., Narayan, D., Sunil, E. J., and Kusumakar, S., 2015. "Dietary supplementation of a novel phytogenic feed additive: effects on nutrient metabolism, antioxidant status and immune response of goats." Animal Production Science, vol. 2, pp. 21-28. Available: http://dx.doi.org/10.1071/AN14770

[26] Duncan, D. B., 1955. "Multiple range and multiple F-test." Biometrics, vol. 11, pp. 1-42.

[27] Teodora, P., Evgeni, P., and Maya, I., 2020. "Effect of black soldier fly (Hermetia illucens) meals on the meat quality of broilers." Agriculture and Food Science, vol. 29, pp. 177-188.

[28] Fascina, S., Khan, R. A., Mughal, N. R., Malik, M. S., Sajjadi, K. E., and Ahmad, A., 2007. "Antimicrobial activity of various effect of Polyalthia longifolia: isolation of active principles from the leaves and barriers." Journal of Phytochemistry, vol. 22, pp. 907-912.

[29] Aduku, A. O., 2004. "Animal nutrition in the tropics: Feeds and feeding in monogastric and ruminant nutrition." Journal of Applied Poultry Research, vol. 13, pp. 628-638.

[30] Alagbe, J. O. and Oluwafemi, R. A., 2019. "Growth performance of weaner rabbits fed Noni (Morinda citrifolia) and Moringa olifera leaf mixture as partial replacement of soya bean meal." International Journal of Advanced Biological and Biomedical Research, vol. 7, pp. 185-195.

[31] Chzmruspollert, M. K., Adewuyi, D., and Adedeji, D. E., 2012. "Ethnobotanical importance and phytochemical analysis of some selected medicinal plants used in Ado-Ekiti Local Government Area, Ekiti State." Journal of Herbal Medicine Research, vol. 23, pp. 0007-0016.

[32] Ma, P. C. N., Faremi, A. Y., and Egwaikhide, P. A., 2010. "Biochemical evaluation of serum metabolites enzymes and hematological indices of broiler chicks fed with varying levels of rumen epithelial scraps in place of fish meal proteins." Research Journal of Poultry Science, vol. 12, pp. 855-857.

[33] Bazer, G. O., Ologbodo, A. D., and Adebiyi, O. A., 2009. "The effect of graded levels of dietary methionine on the hematology and serum biochemistry of broilers." International Journal of Poultry Science, vol. 9 , pp. 158-161.

[34] Marc, R. J. and Wu, G., 2009. "Glutamine, arginine, and leucine signalling in the intestine." Amino Acids, vol. 37, pp. 111-22.

[35] Kimura, H., 2010. "Hydrogen sulphide: from brain to gut." Antioxidant Redox Signal, vol. 12, pp. 1111-23.

[36] Tan, B., Yin, Y., Kong, X., Li, P., Li, X., Gao, H., Li, X., Huang, R., and Wu, G., 2010. "L-Arginine stimulates proliferation and prevents endotoxin-induced death of intestinal cells." Amino Acids, vol. 38, pp. 1227-35. 
[37] Yin, Y. L., Yao, K., Liu, Z. J., Gong, M., Ruan, Z., Deng, D., Tan, B. E., Liu, Z. Q., and Wu, G., 2010. "Supplementing L-leucine to a low-protein diet increases tissue protein synthesis in weanling pigs." Amino Acids, vol. 23, pp. 34-49.

[38] Brosnan, J. T. and Brosnan, M. E., 2010. "Creatine metabolism and the urea cycle." Journal of Molecular Genetics and Metabolism, vol. 100, pp. S49-52.

[39] Wu, Bazer, F. W., Burghardt, R. C., Johnson, G. A., Kim, S. W., Knabe, D. A., Li, X. L., Satterfield, M. C., and Smith, S. B., 2010. Functional amino acids in swine nutrition and production. In: Doppenberg J, editor. Dynamics in animal nutrition. Wageningen, The Netherlands: Wageningen Academic Publishers. pp. 69-98.

[40] Baker, D. H., 2009. "Advances in protein-amino acid nutrition of poultry." Amino Acids., vol. 37, pp. 29-41.

[41] Wu, Ruan, Z., Gao, Y. L., Yin, Y. L., Zhou, X. H., Wang, L., Geng, M. M., Hou, Y. Q., and Wu, G., 2010. "Dietary supplementation with L-arginine or N-carbamylglutamate enhances intestinal growth and heat shock protein-70 expression in weanling pigs fed a corn- and soybean meal-based diet." Amino Acids., vol. 39, pp. 831-9.

[42] McKnight, J. R., Satterfield, M. C., Jobgen, W. S., Smith, S. B., Spencer, T. E., Meininger, C. J., McNeal, C. J., and Wu, G., 2010. "Beneficial effects of L-arginine on reducing obesity: potential mechanisms and important implications for human health." Amino Acids., vol. 39, pp. 349-57.

[43] Palii, S. S., Kays, C. E., Deval, C., Bruhat, A., Fafournoux, P., and Kilberg, M. S., 2009. "Specificity of amino acid regulated gene expression: analysis of gene subjected to either complete or single amino acid deprivation." Amino Acids, vol. 37, pp. 79-88.

[44] Talebi, A., Asri-Rezaei, S., Rozeh-Chai, R., and Sahraei, R., 2005. "Comparative studies on haematological values of broiler strains (Ross, Cobb, Arbo-acres and Arian)." International Journal of Poultry Science, vol. 4, pp. 573-579.

[45] Subhadarsini, M. and Silpa, M. G., 2020. "Comparative haematology and biochemical parameters of Indigenous broiler chicken." International Journal of Scientific Technology Research, vol. 9, pp. 972-978.

[46] Ibrahim, S., 2012. "Browning reactions in foods." Biochemistry of Foods, vol. 12, pp. 245-289.

[47] Islam, M. S., Lucky, N. S., Literak, I., Ahad, A., Rahman, M. M., and Siddiui, M. S. I., 2004. "Changes of haematological parameters of fayoumi, assil and local chickens reared in Sylhet region in Bangladesh." International Journal of Poultry Science, vol. 3, pp. 144-147.

[48] Abdi-Hachesoo, B., Talebi, A., and Asri-Rezaei, S., 2011. "Comparative study on blood profile of indigenous and Ross-308 broiler breeders." Global Veterinary Journal, vol. 7, pp. 238-241.

[49] Fugdge, A. M., 2000. Laboratory medicine: Avian and exotic pets. Philadelpia: W.B Saunders Company.

[50] Nse Abasi, N. E., Mary, E. W., Uduak, A., and Edem, E. A. O., 2014. "Haematological parameters and factors affecting their values." Journal of Agricultural Science, vol. 2, pp. 37-47.

[51] Omokore, E. O. and Alagbe, J. O., 2019. "Efficacy of dried Phyllantus amarus leaf meal as an herbal feed additive on the growth performance, haematology and serum biochemistry of growing rabbits." International Journal of Academic Research and Development, vol. 4, pp. 97-104.

[52] Isaac, L. J., Abah, G., Akpan, B., and Ekaette, I. U., 2013. "Haematological properties of different breeds and sexes of rabbits." In Proceedings of the 18th Annual Conference of Animal Science Association of Nigeria. pp. 24-27.

[53] Ugwuene, M. C., 2011. "Effect of dietary palm kernel meal for maize on the haematology and serum chemistry of broiler Turkey." Nigerian Journal of Animal Science, vol. 13, pp. 93-103.

[54] Iwuji, M. and Herbert, P. O., 2012. "Effect of crude oil polluted water on the hematology of cockerel reared under intensive system." International Journal of Poultry Science, vol. 10, pp. 287-289.

[55] Obajuluwa, O. V., Sanwo, K. A., Egbeyale, L. T., and Fafiolu, O. A., 2020. "Performance, blood profile and gut morphometry of broiler chickens fed diets supplemented with Yohimbe (Pausynistalia yohimbe) and Larvacide." Journal of Veterianary and Animal Science, Available: https://www.sciencedirect.com/science/article/pii/S2451943X20300405

[56] Olafadehan, O. A., Oluwafemi, R. A., and Alagbe, J. O., 2020. "Performance, haemato-biochemical parameters of broiler chicks administered Rolfe (Daniellia oliveri) leaf extract as an antibiotic alternative." Advances in Research and Reviews, vol. 1, p. 4.

[57] Livingston, M. L., Cowieson, A. J., Crespo, R., Hoang, V., Nogal, B., and Browning, M., 2020. "Effect of broiler genetics, age and gender on performance and Blood Chemistry." Heliyon, vol. 6, p. e 04400.

[58] Obiakaonu, H. O., Okoli, I. C., Opara, M. N., Okoro, V. M. O., Ogbuewu, I. P., Etuk, E. B., and Udedibie, A. B. I., 2011. "Haematological and serum biochemical indices of starter broilers fed neem leaf meal." Online Journal of Animal and Feed Research, vol. 1, pp. 150-154.

[59] Simeraks, O. I., Ayagbemi, A. A., and Oyewale, J. O., 2004. "Diurnal fluctuation in haematological parameters of the domestic fowl in the hot humid tropics." International Journal of Poultry Science, vol. 8, pp. 247-251.

[60] Akande, T. and Odunsi, A. A., 2012. "Nutritive value and biochemical changes in broiler chickens fed detoxified castor kernel cake based diets." African Journal of Biotechnology, vol. 11, pp. 2904-2911.

[61] OIabanji, R. O., Farinu, G. O., Akinlade, J. A., Ojebiyi, O. O., Odunsi, A. A., and Akingbade, A. A., 2007. "Studies on haematological and serum biochemical characteristics of weaner rabbits fed different levels of wild sunflower (tithonia diversifolia hemsl a. Gray) leaf- blood meal mixture." Internation Journal of Agriculture and Apiculture Research, vol. 4, pp. 80-89. 
[62] Abdel, Wareth, A. A., and Lohakare, J. D., 2014. "Effect of dietary supplementation of peppermint on performance, egg quality and serum metabolic profile of Hy-Line brown hens during the late laying period." Animal Feed Science and Technology, vol. 197, pp. 114-120.

[63] Cho, S., Alden, N., and Lee, K., 2014. "Pathways and functions of gut microbiota metabolism impacting host physiology." Current Opinion on Biotechnology, vol. 36, pp. 137-145.

[64] Hollman, P. C., 2001. "Evidence for health benefits of plant phenols: Local or systemic effects." Journal of Science Food Agriculture, s, vol. 81, pp. 842-852.

[65] Ojewuyi, O. B., Ajiboye, T. O., Adebanjo, E. O., Balogun, A., and Mohammed, A. O., 2014. "Proximate composition, phytochemical and mineral contents of young and mature Polyalthia longifolia Sonn." leaves Fountain Journal of Natural and Applied Sciences, vol. 3, pp. 10-19.

[66] Lan, P. T. N., le Binh, T., and Benno, Y., 2013. "Impact of two probiotic Lactobacillus strains feeding on fecal lactobacilli and weight gains in chicken." J. Gen. Appl. Microbiol., vol. 49, pp. 29-36. 